\title{
Cassiopea andromeda (Forsskall, 1775) in the Gulf of Kutch, India: initial discovery of the scyphistoma, and a record of the medusa in nearly a century
}

Amruta Prasade*, Pooja Nagale and Deepak Apte

\begin{abstract}
Background: Cassiopea andromeda is reported here after long gap of almost a century from the Gulf of Kutch, Gujarat. This is the first record of scyphistoma form of the species from India and first record of the medusa from the Arambhada coast.
\end{abstract}

Results: An upside down scyphozoan jellyfish Cassiopea andromeda belong to family Cassiopeidae. Identification and description of medusa and scyphistomae were given based on morphological characters.

Conclusions: This paper discusses about the variation in colour form, aggregation of medusae and morphology of polyp.

Keywords: Upside down jellyfish, Scyphistoma, Cassiopeidae, Arambhada, Narara, Gujarat

\section{Introduction}

The rhizostome scyphozoan Cassiopea andromeda is referred to Cassiopeidae, an unusual family of so-called upside-down jellyfishes that comprises the single genus Cassiopea and six currently recognized species (Holland, et al, 2004). Circumtropical in distribution (Schembri et al., 2010), these species most often occur in shallow bays, intertidal sand, mangrove mudflats and lagoons (Browne, 1916).

The species has been recorded previously in India as C. andromeda var. maldivensis from Armara, Gulf of Kutch, Gujarat (Browne, 1916) and from Krusadai Island, Gulf of Mannar, Tamilnadu (Rao, 1931), and as C. andromeda from Madras (Menon 1930, 1936) and the Andaman Islands (Venkataraman et al. 2012). Gopalkrishnan (1970) reported Cassiopea sp. from Adatra, Gujarat, but provided no photographs or information on its morphology. Cassiopea andromeda has been implicated as an invasive or alien species worldwide (Özgür and Öztürk, 2008; Çevik, et al., 2006; Katsanevakis, 2011; Zenetos et al, 2005, 2011) and is referred as ecologically

\footnotetext{
* Correspondence: amrutaprsade@gmail.com

Bombay Natural History Society, Mumbai 400 001, India
}

important species considering its invasive distribution (Heins et al, 2015).

The global phylogeography of Cassiopea spp. from the Pacific and Indian oceans was investigated by Holland et al. (2004) who provided molecular evidence of the cryptic nature of the genus and of problems raising with species identification based on morphological characters only.

Cassiopea andromeda is a carnivorous species that uses nematocysts to capture its prey. Nutrition is also obtained from photosynthetic dinoflagellate algae (zooxanthellae) present in the oral arms on the ventral side of the body. As with most scyphozoans, the life cycle of $C$. andromeda includes a sessile polypoid or scyphistoma stage eventually giving origin to the medusa stage through monodisk strobilation with a single ephyra developing by the oral part of the polyp (Heins et al, 2015).

Cassiopeid medusae were observed during 2013 at Arambhada, Gulf of Kutch (Fig. 1). Medusa and scyphistoma polyp specimens were tentatively identified as C. andromeda (sensu Holland et al 2004), based on descriptions of Mayer (1910) and with the support of D. K. Hofmann who confirmed morphology 


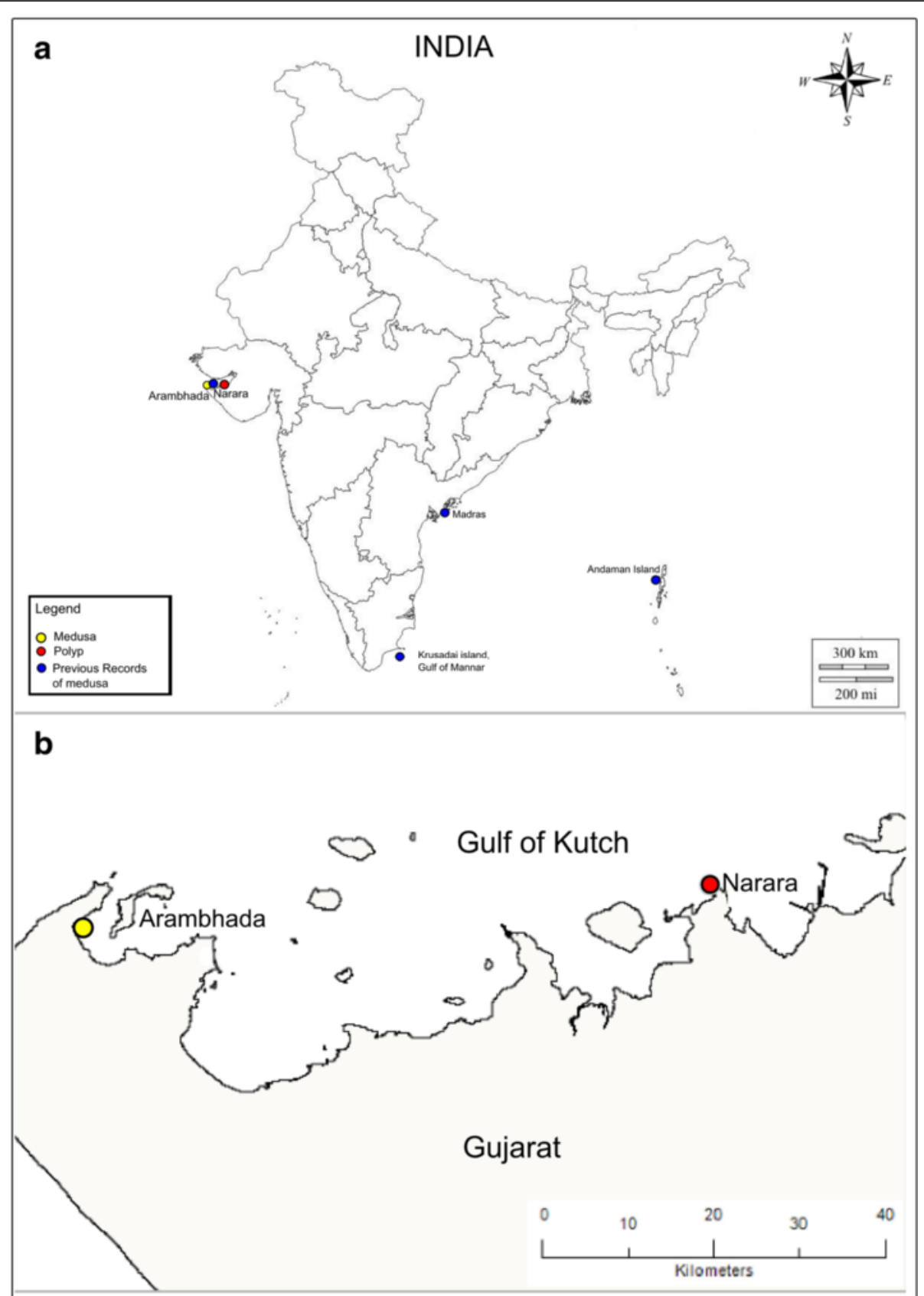

Fig. 1 a Map of India showing present and previous records of Cassiopea andromeda. b Current records from Gujarat; Arambhada (Medusa) and Narara (Polyp)

scyphistoma, type of budding and nematocysts are similar to C. andromeda (personal communication, 12 February 2015). Our report constitutes the first record of the scyphistoma of Cassiopea sp. in India, and the first record of the medusa from Gujarat since 1916. Following its discovery, the Wildlife Trust of India gave accounts of the species in news articles during 2014, reporting it from "India's first jellyfish lake".

\section{Material and methods}

Scyphistomae from Narara, and medusae from the Arambhada coast, both in the Gulf of Kutch, Gujarat (Fig. 1), were observed on 7 January, 2013 and 28 December, 2013 and average sea water temperature recorded was $21.8{ }^{\circ} \mathrm{C}$ and $20.4{ }^{\circ} \mathrm{C}$ respectively. Few scyphistomae collected were found attached to rock at intertidal area of dead coral reef. As specimens were preserved immediately, no further study could be made. 
Our field work was undertaken under the All India Co-ordinated Project on Taxonomy (AICOPTAX). Polyps were preserved using $4 \%$ formalin in sea water and deposited in collections at the Bombay Natural History Society (ACC. No. BNHS- HY- 0410). Polyp morphology was studied using a stereomicroscope (Leica EZ4 D). Nematocyst studies were carried out following the simple squash method (Östman, 2000) using a compound microscope (Leica DM750). Specimens of the medusa stage were not collected, although photographic documentation was made of both medusa and polyp.

\section{Results}

Class Scyphozoa Goette, 1887

Order Rhizostomeae Cuvier, 1799

Family Cassiopeidae L. Agassiz, 1862

Genus Cassiopea Péron \& Lesueur, 1810

Species Cassiopea andromeda (Forsskål, 1775)

\section{Description of observed medusae (Fig. 2)}

Umbrella circular, flattened, $10 \mathrm{~cm}$ to $15 \mathrm{~cm}$ in diameter, usually with subumbrellar surface facing upwards and exumbrella facing downwards; oral arms 8-9 in number, slightly longer than umbrella radius, branched, with about 4 side branches supporting many filaments with zooxanthellae; each arm with numerous small and about 6 large, club-shaped vesicles. Medusae brown, blue or green; umbrella usually brown with white patches on rim.

\section{Description of observed scyphistomae (Fig. 3)}

Polyps attached to hard rocky substratum, lemon yellow colored; hypostome slender, straight (Fig. 3a); fully- grown specimens about 3-4 $\mathrm{mm}$ high, deep, cup- or bowl-shaped; calyx $1.35 \mathrm{~mm}$; after preservation hypostome looked quadrate, orifice with outward-folded lips (Fig. 3c); tentacles long, slender, encircling mouth, about 30 to 33 in number. Stalk of polyp about $2-2.5 \mathrm{~mm}$ long. Some polyps with single or two connected buds, emerging from lower part of calyx (Fig. $3 \mathrm{~b}$ and $\mathrm{d}$ ); buds spindle-shaped, about $0.3 \mathrm{~mm}$ in length.

\section{Cnidome}

The nematocyst complement observed in tentacles of the scyphistoma comprised large and small microbasic euryteles, birhopaloids and isorhizas (Fig. 3e, f). As the nematocyst analysis was carried out after preservation of polyp, no discharged capsules were observed, for detail description of nematocysts refer Heins et al, 2015.

\section{Discussion}

Aggregations of Cassiopea andromeda were observed on soft muddy bottoms of the Arambhada coast during low tide. That habitat was dominated by various types of algae, sponges, ascidians and bryozoans. Various color forms of $C$. andromeda were observed, including blue, green, and brown. In a 10-m-long transect within a channel, aggregations of about 15 specimens were observed. Specimens ranged from $10 \mathrm{~cm}$ to $15 \mathrm{~cm}$ in diameter, whereas collections by Hornell in 1905 (Browne 1916) mentioned sizes from $2 \mathrm{~cm}$ to $6 \mathrm{~cm}$.

Significance of endosymbiotic dinoflagellate in carbon metabolism and strobilation in C. andromeda has been studied by Hofmann and Kremer, 1981. They concluded that strobilation is just supported but not triggered by dinoflagellate or zooxanthellae photosynthetic activity.

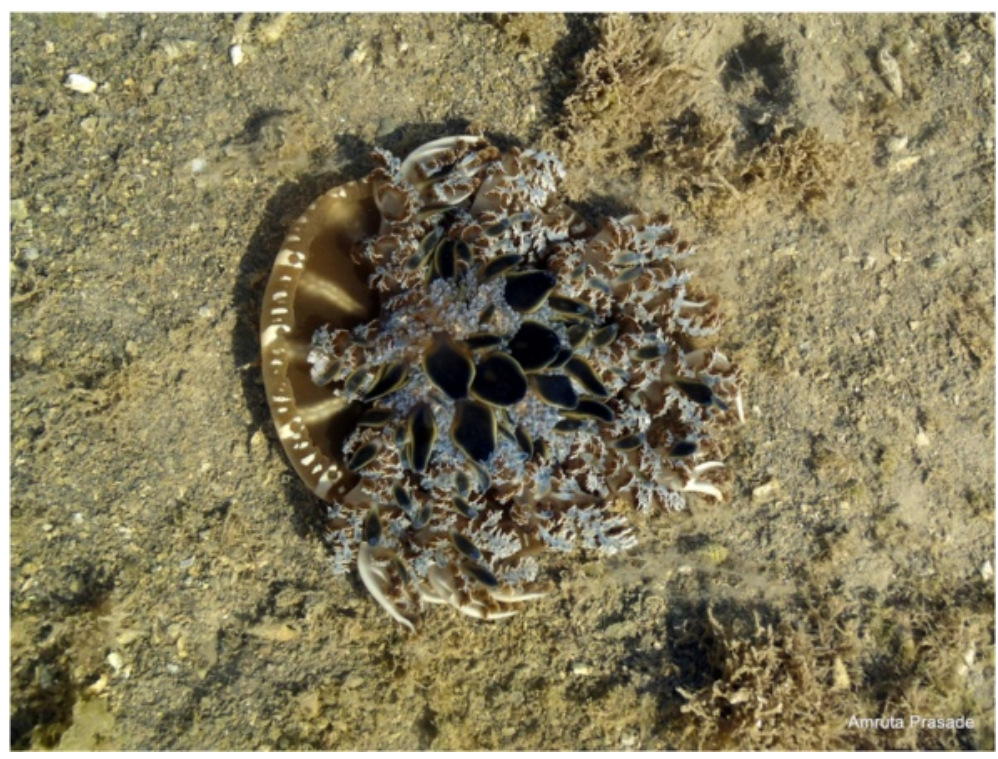

Fig. 2 Medusa of Cassiopea andromeda, an upside down Jellyfish (ventral view) from Arambhada, Gujarat, India 


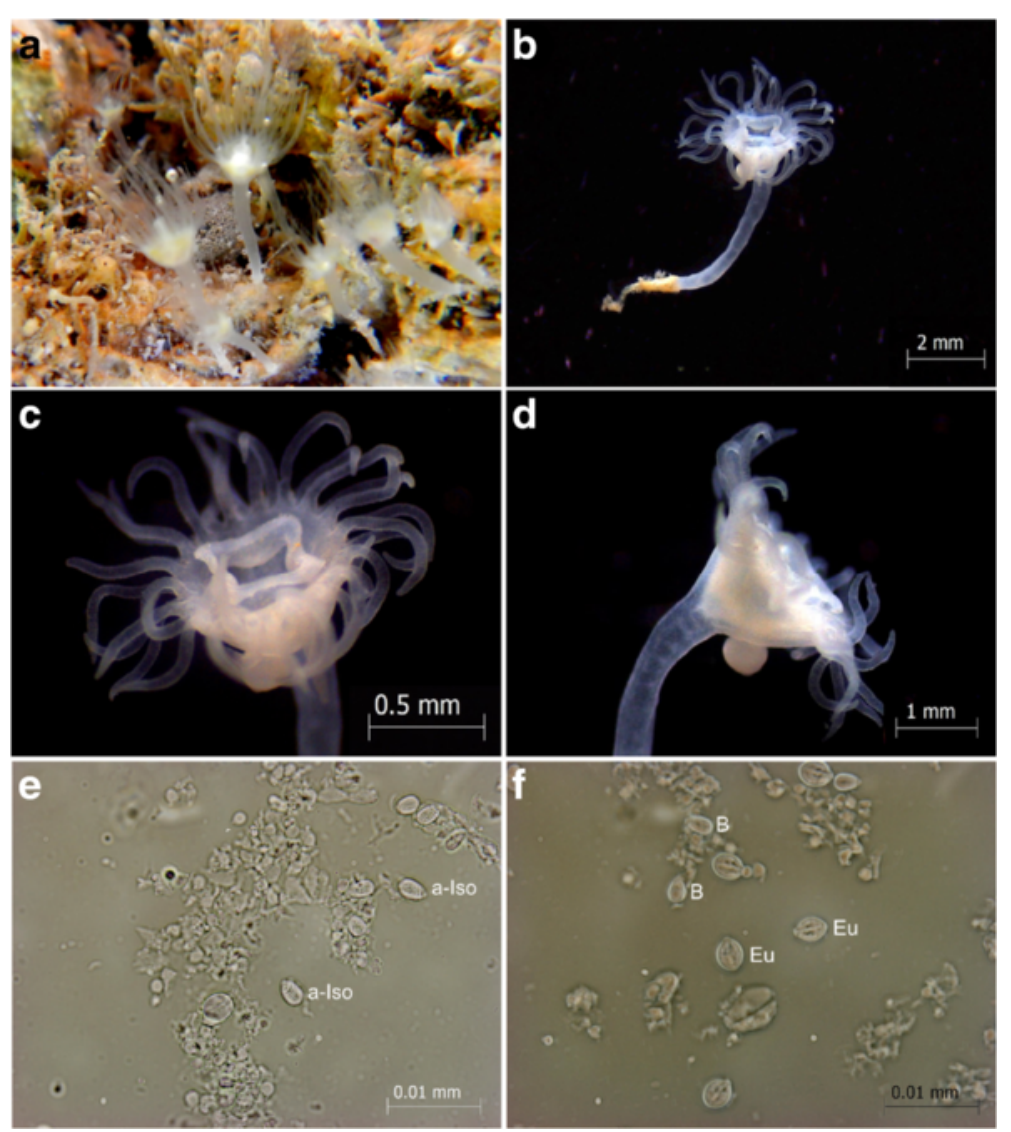

Fig. 3 Scyphistoma of Cassiopea andromeda: a Mature scyphistoma in life, b scyphistoma after preservation, c scyphistoma showing tentacles, $\mathbf{d}$ spindle shaped bud emerging from calyx, e-f various nematocysts in tentacle. a-lso: a-isorhiza, B: Birhopaloids, Eu: Euryteles; Scale bars: B, 2 mm; C, $0.5 \mathrm{~mm} ; \mathrm{D}, 1 \mathrm{~mm} ; \mathrm{E}-\mathrm{F}, 0.01 \mathrm{~mm}$

Various scientists have worked on the scyphistomae of Cassiopea spp. Hofmann and Gottlieb, 1991 have studied the asexual reproduction from scyphistomae of Cassiopea andromeda through spindle shaped bud formation, illustrating stages in bud formation. Kehls et al. (1999) studied the induction of head and foot formation in buds of $C$. andromeda by the protein phosphatase inhibitor cantharidin. They gave an elaborate diagram of the scyphistomae, which describes morphology of polyp like shape of hypostome (quadrangular) and bud. A recent research by Heins et al, 2015 gave elaborated knowledge about the schyphistomae of C. andromeda, its bud development and nematocysts composition.

\section{Conclusions}

Medusa of Cassiopea andromeda was reported from the Gulf of Kutch, Gujarat after a gap of a century while scyphistomae easily confirmed up to genus level based on descriptions about polyp morphology, nematocyst composition and by the experts' comments.

\section{Abbreviations}

AICOPTAX, All India Co-ordinated Project on Taxonomy; ACC. No., Accession Number; BNHS, Bombay Natural History Society; HY, Hydrozoa; cm, Centimeter; $\mathrm{mm}$, millimeter

\section{Acknowledgement}

We thank the Chief Conservation of Forests, Marine National Park, and Gujarat Forest Department for providing necessary permission to undertake the survey. We are also grateful to Dr. Andre Morandini and Dr. D. K. Hofmann for help in identification. We also thank Dr. Dale Calder for language editing. Thanks are also extended to all team members for assistance in the field.

\section{Availability of data and materials} Not Applicable.

\section{Authors' contributions}

AP first reported medusa and polyps during field surveys, identified medusa, and drafted the manuscript. PN identified polyps, carried out nematocyst isolation and helped to draft the manuscript. DA guided the study and final editing of the manuscript. All authors read and approved the final manuscript. 


\section{Competing interests}

The authors declare that they have no competing interests.

Received: 23 May 2016 Accepted: 3 June 2016

Published online: 04 July 2016

\section{References}

Agassiz L. Contributions to the natural history of the United States of America, vol. 4. Boston: Little Brown \& Co; 1862. p. 380pp.

Browne ET. Notes on some jelly-fishes from Okhamandal in Kattiawar, collected by Mr. James Hornell in 1904-5. Report to the Government of Baroda on the Marine Zoology of Okhamandal in Kattiawar, Part II. 1916. p. 151-5.

Cevik C, Erkol IL, Toklu B. A new record of an alien jellyfish from the Levantine coast of Turkey- Cassiopea andromeda (Forsskål, 1775) (Cnidaria: Scyphozoa: Rhizostomae). Aquat Invasions. 2006;1(3):196-7.

Cuvier GD. Sur l'organization de l'animal nommé méduse. J Phys Chimie dHist Nat Arts. 1799;49:436-40.

Forsskål P. Descriptiones Animalium Avium, Amphibiorum, Piscium, Insectorum, Vermium; quae in Itinere orientali observavit. Petrus Forskål. Post Mortem Auctoris editit Carsten Niebuhr. Adjuncta est materia Medica Kahirina. Hauniae, Heineck et Faber. 1775.

Goette A. Abhandlungen zur Entwickelungsgeschichte der Tiere: Heft. Entwickelungsgeschichte der Aurelia aurita und Cotylorhiza tuberculata (Vol. 4). L. Voss. 1887

Gopalkrishnan P. Some observations on the shore ecology of the Okha coast. J Mar Biol Assoc India. 1970;12(1 \& 2):15-34.

Heins A, Glatzel T, Holst S. Revised descriptions of the nematocysts and the asexual reproduction modes of the scyphozoan jellyfish Cassiopea andromeda (Forskål, 1775). Zoomorphol. 2015;1-16.

Hofmann DK, Gottlieb M. Bud formation in the scyphozoan Cassiopea andromeda: epithelial dynamics and fate map. Hydrobiologia. 1991;261/217:53-9.

Hofmann DK, Kremer BP. Carbon metabolism and strobilation in Cassiopea andromeda (Cnidaria: Scyphozoa): Significance of endosymbiotic dinoflagellates. Mar Biol. 1981;65:25-33.

Holland BS, Dawson MN, Crow GL, Hofmann DK. Global phylogeography of Cassiopea (Scyphozoa: Rhizostomeae): molecular evidence for cryptic species and multiple invasions of the Hawaiian Islands. Mar Biol. 2004;145(6):1119-28.

Katsanevakis S. Rapid assessment of the marine alien megabiota in the shallow coastal waters of the Greek islands, Paros and Antiparos, Aegean Sea. Aquat Invasions. 2011;6 Suppl 1:133-7.

Kehls NE, Herrmann K, Berking S. The protein phosphatase inhibitor cantharidin induces head and foot formation in buds of Cassiopea andromeda (Rhizostomae, Scyphozoa). Int J Dev Biol. 1999;43:51-8.

Mayer AG. Medusae of the World. Volume III. The Scyphomedusae. Carnegie Inst Wash Publication. 1910;109(3):499-735

Menon MGK. Scyphomedusae of Krusadai Island. Bulletin of Madras Government Museum. Natural History Section 1. Madras, India: Printed by the superintendent, Govt. Press; 1936. p. 1-9.

Menon MGK. The Scyphomedusae of Madras and the neighboring coast. Natural History Section Vol. 3, No. 1. Madras, India: Printed by the superintendent, Govt. Press; 1930

Östman C. A guideline to nematocyst nomenclature and classification, and some notes on the systematic value of nematocysts. Sci Marina. 2000; 64(Supplement 1):31-46.

Özgür E, Öztürk B. A population of the alien jellyfish, Cassiopea andromeda (Forsskål, 1775) [Cnidaria: Scyphozoa: Rhizostomae] in the Ölüdeniz Lagoon, Turkey. Aquat Invasions. 2008;3(4):423-8.

Péron F, Lesueur CA. Tableau des caractères génériques et spécifiques de toutes les espèces de méduses connues jusqu'à ce jour. In Annales Muséum Hist Nat. 1810;14:325-66.

Rao HS. Notes on Scyphomedusae in the Indian museum. Rec Indian Museum. 1931;33:25-62.

Schembri PJ, Deidun A, Vella PJ. First record of Cassiopea andromeda (Scyphozoa: Rhizostomeae: Cassiopeidae) from the central Mediterranean Sea. Mar Biodivers Rec. 2010;3:e6

Venkataraman K, Raghunathan C, Raghuraman R, Sreeraj CR. Marine Biodiversity. 2012. p. 1-164. (Published by the Director, Zoological Survey India, and Kolkata) Published: May, 2012 ISBN 978-81-8171-307-0.

Zenetos A, Çinar ME, Pancucci-Papadopoulou MA, Harmelin JG, Furnari G, Andaloro $\mathrm{F}$, et al. Annotated list of marine alien species in the Mediterranean with records of the worst invasive species. Mediterr Mar Sci. 2005;6(2):63-118.
Zenetos A, Katsanevakis S, Poursanidis D, Crocetta F, Damalas D, Apostolopoulos $\mathrm{G}$, et al. Marine alien species in Greek Seas: additions and amendments by 2010. Mediterr Mar Sci. 2011;12(1):95-120.

\section{Submit your next manuscript to BioMed Central and we will help you at every step:}

- We accept pre-submission inquiries

- Our selector tool helps you to find the most relevant journal

- We provide round the clock customer support

- Convenient online submission

- Thorough peer review

- Inclusion in PubMed and all major indexing services

- Maximum visibility for your research

Submit your manuscript at www.biomedcentral.com/submit 